\title{
Mammals in the mountains: An historical review and updated checklist of the mammals of the Mountain Zebra National Park
}

\begin{tabular}{|c|c|}
\hline $\begin{array}{l}\text { Author: } \\
\text { Daniel M. Park }\end{array}$ & $\mathrm{er}^{1,2}$ \\
\hline $\begin{array}{l}\text { Affiliations: } \\
{ }^{1} \text { School of Biol } \\
\text { Environmental } \\
\text { Faculty of Agri } \\
\text { Natural Scienc } \\
\text { of Mpumalang } \\
\text { South Africa }\end{array}$ & $\begin{array}{l}\text { ogy and } \\
\text { Sciences, } \\
\text { culture and } \\
\text { es, University } \\
\text { sa, Mbombela, }\end{array}$ \\
\hline $\begin{array}{l}{ }^{2} \text { Wildlife and R } \\
\text { Management } \\
\text { Group, Depart } \\
\text { Zoology and Er } \\
\text { Rhodes Univer } \\
\text { Makhanda, So }\end{array}$ & $\begin{array}{l}\text { Reserve } \\
\text { ment of } \\
\text { ntomology, } \\
\text { sity, } \\
\text { uth Africa }\end{array}$ \\
\hline $\begin{array}{l}\text { Corresponding } \\
\text { Daniel Parker, } \\
\text { daniel.parker@ }\end{array}$ & $\begin{array}{l}\text { author: } \\
\text { Dump.ac.za }\end{array}$ \\
\hline $\begin{array}{l}\text { Dates: } \\
\text { Received: } 30 \mathrm{~A} \\
\text { Accepted: } 26 \text { I } \\
\text { Published: } 12\end{array}$ & $\begin{array}{l}\text { pr. } 2021 \\
\text { May } 2021 \\
\text { July } 2021\end{array}$ \\
\hline $\begin{array}{l}\text { How to cite th } \\
\text { Parker, D.M., } 2 \\
\text { 'Mammals in t } \\
\text { An historical re } \\
\text { updated check } \\
\text { mammals of th } \\
\text { Zebra National } \\
\text { Koedoe 63(1), } \\
\text { https://doi.org } \\
\text { koedoe.v63i1. }\end{array}$ & $\begin{array}{l}\text { is article: } \\
021 \text {, } \\
\text { he mountains: } \\
\text { eview and } \\
\text { klist of the } \\
\text { e Mountain } \\
\text { I Park', } \\
\text { a1683. } \\
\text { /10.4102/ } \\
1683\end{array}$ \\
\hline $\begin{array}{l}\text { Copyright: } \\
\text { @ 2021. The A } \\
\text { Licensee: AOSI } \\
\text { is licensed und } \\
\text { Creative Comn } \\
\text { Attribution Lic }\end{array}$ & $\begin{array}{l}\text { uthors. } \\
\text { IS. This work } \\
\text { ler the } \\
\text { nons } \\
\text { ense. }\end{array}$ \\
\hline Read online: & \\
\hline 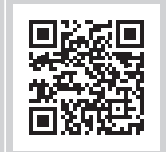 & $\begin{array}{l}\text { Scan this QR } \\
\text { code with your } \\
\text { smart phone or } \\
\text { mobile device } \\
\text { to read online. }\end{array}$ \\
\hline
\end{tabular}

Based on published and unpublished records, together with original data collected from regular field trips over a 15-year period, 68 mammal species have been reliably recorded from the Mountain Zebra National Park. I assessed the current status of all mammal species, in relation to park expansion and research effort over time (1937-2020). Although numerous large and charismatic mammal species have been reintroduced to the park since it was gazetted in 1937, both in an attempt to restore the historical diversity of the region and to attract tourists, research effort in the surveying of the smaller and more cryptic mammal species has been sorely lacking. I recommend that future survey work targets the small, mostly fossorial mammals (i.e. golden and rodent moles, elephant shrews and gerbils) and insectivorous bats.

Conservation implications: This work provides critical presence data for several mammal species from an important protected area that straddles three biomes in South Africa.

Keywords: species richness; biodiversity; surveys; time-series; South Africa; semi-arid.

\section{Introduction}

South Africa boasts a network of 20 national parks that are situated across a range of vegetation biomes. The primary function of these national parks is to protect the ecological integrity of these various natural ecosystems for current and future generations (Bezuidenhout \& Brown 2008). However, several national parks within this network were originally gazetted in an attempt to preserve a single species (often large mammals) because of pressure from over-hunting or poaching (e.g. Addo Elephant National Park and Bontebok National Park). The Mountain Zebra National Park (hereafter MZNP) is one such 'single-species' national park. The park was founded in 1937 to protect the endangered Cape mountain zebra (Equus zebra zebra). To sustain the viability of the mountain zebra population, the park was extended in 1964 and 1996 by incorporating various farms adjacent to the park (Bezuidenhout \& Brown 2008). The park was expanded again in 2002, but by this stage, the conservation and management focus had shifted more towards the conservation of biodiversity as a whole, rather than just the viability of the mountain zebra population (SANParks 2016).

Although the MZNP has been the focus of much mammalian-related research since it was proclaimed, the park has expanded to 12 times its original size since 1937, and the current checklist of mammals appears to be a transcript of several earlier (flawed) lists. In addition, since the proclamation of the park, several technological advancements (e.g. the introduction of passive infra-red camera traps) are likely to have improved the detectability of some species that other more traditional techniques failed to detect in the past (De Bondi et al. 2010). Moreover, the nomenclature (and, effectively, the number) of individual mammal species may change over time as new knowledge about the evolutionary history of a species or group of species becomes available and they are either divided or synonymised (Taylor et al. 2019). Thus, the aims of this study were to provide an historical review of the mammal species of the MZNP and to update the mammal checklist for the park.

\section{Materials and methods}

\section{Study site}

The MZNP $\left(32^{\circ} 18^{\prime} \mathrm{S}, 2^{\circ} 24^{\prime} \mathrm{E}\right)$ is a South African National Park (SANParks) and initially included only the farm 'Babylons Toren' which was just 1712 Ha in size (Grobler \& Hall-Martin 1982). In 1964, the park increased to 6536 Ha with the acquisition of the farms 'Zebrahoek', 'Pretoriuskraal', 
'Wildepaardenek', 'Sneeuberg' and a portion of 'Doornhoek' (Grobler \& Hall-Martin 1982). The park stayed at this size until 1996 when the farms 'Ingleside', 'Welgedacht', 'De Rust', 'Ebenhaeser', 'Jurisdam', 'Zeekoeigat' and the remaining portion of 'Doornhoek' were acquired, taking the park to $18000 \mathrm{Ha}$ (Craig, Hulley \& Parker 2005). These newly acquired farms only became available for use by the non-volant animals residing in the park in the early 2000s when they were adequately fenced into the original $6536 \mathrm{Ha}$ portion. In approximately 2002, the farms 'Toekoms' (also referred to as 'Sonnenrust') on the western boundary and portions of farm numbers 595 and 596 (previously owned by WP Erasmus) on the southern tip were incorporated into the park, taking it to 21412 Ha (Figure 1, SANParks 2016). Although the park is now officially $28386 \mathrm{Ha}$ in extent, the additional areas are not located directly adjacent to the existing park and have not yet been gazetted as national park land (SANParks 2016).

The park is situated in a transition zone between the NamaKaroo, Grassland and Albany Thicket biomes and is characterised by a semi-arid climate (Mucina et al. 2006). The southern section of the park is mountainous with altitudinal peaks of up to $1960 \mathrm{~m}$, whereas the northern section consists of lower lying areas ranging from $1000 \mathrm{~m}$ to $1500 \mathrm{~m}$.

\section{Historical mammal records and updating of the mammal checklist}

Mammal records for the MZNP since its proclamation were collated from (1) relevant published articles, (2) relevant unpublished reports and student theses, (3) unpublished, annual and individual field trip reports submitted to SANParks for the period 2001-2016 under approved projects 2000-11-08RBER and BISC864 and (4) direct observations during field trips not captured under (3).

For published articles, a Google Scholar search was conducted using the search term 'Mountain Zebra National Park'. This search produced 1200 potential articles which I then screened to determine their relevance. If an article's title alluded to the manuscript including records for mammals, I read the abstract (where applicable) to ascertain if such records were in fact provided. In cases where mammal records were included in the manuscript, these data were extracted (Table 1). The articles that included mammal records then

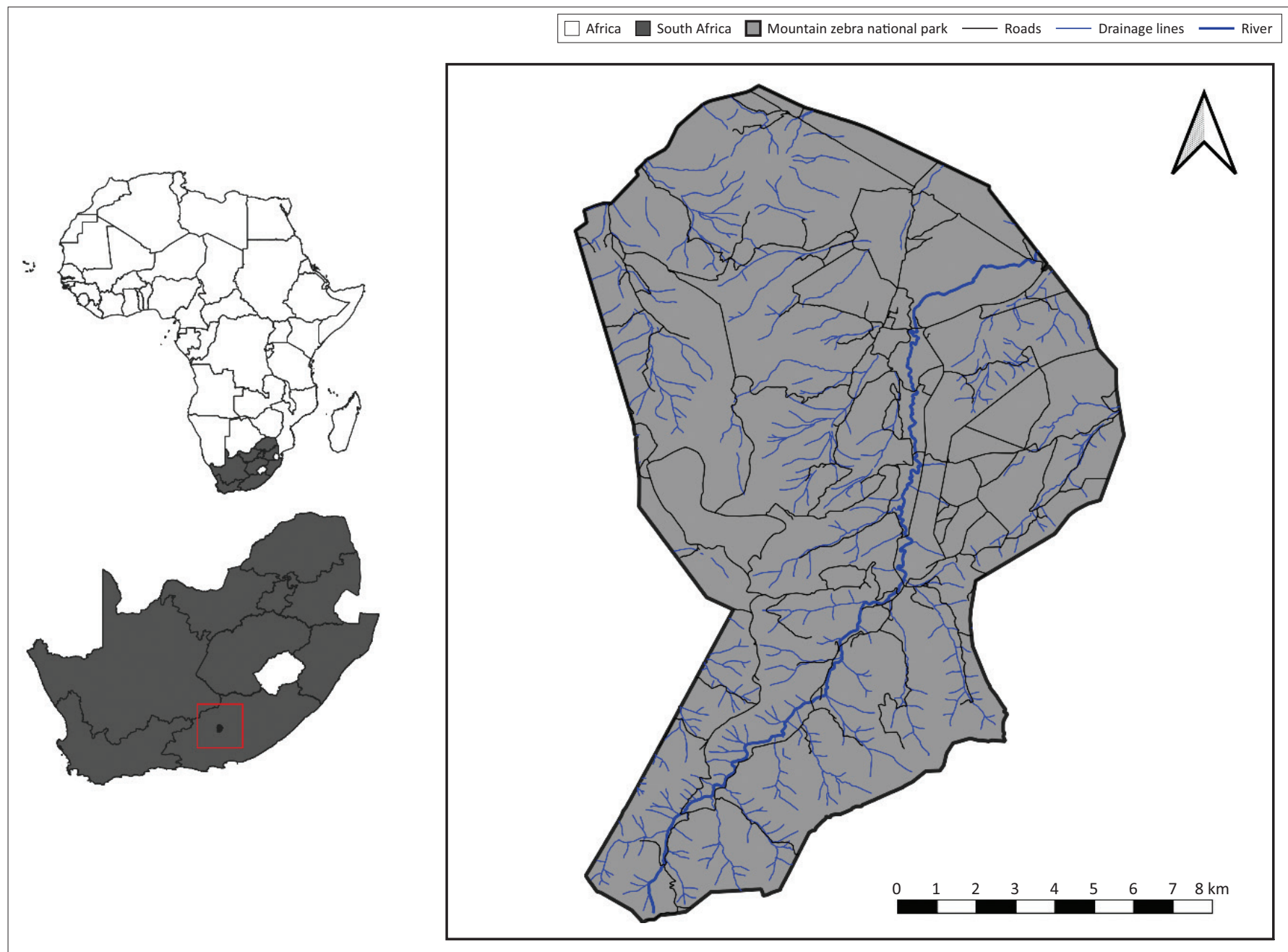

Source: Comley, J., 2016, 'Population assessment and feeding ecology of brown hyaenas (Hyaena brunnea) in Mountain Zebra National Park, Eastern Cape, South Africa', MSc thesis, Department of Zoology and Entomology, Rhodes University, Grahamstown.

FIGURE 1: The current (2020) extent of the Mountain Zebra National Park in the Eastern Cape, South Africa. 
had their reference lists perused to determine the relevance of any citation which was not included in the list of articles from the original Google Scholar search. In most instances, such citations were unpublished internal reports or student theses. Wherever possible, I attempted to obtain copies of these reports and or theses.

For unpublished reports, student theses and annual and field trip reports, relevant sections (including appendices) were checked and any reliable mammal data were extracted (Table 1). For the unpublished or grey literature, I deemed mammal presence data reliable only when it was supported by firm evidence (i.e. a specimen had been collected, the animal had been reliably observed by the authors or photographic evidence was provided).

The extracted data were then organised taxonomically and chronologically to match the four separate periods of park expansion described above (Table 1). Only in instances where a species had apparently not been recorded during a certain period, but was known to be present in the park, were direct observations used. Typically, the inclusion of such direct observations was for the more charismatic and larger species or those that could not be easily confused with any other species for the period 1999-2002. For example, published and unpublished data demonstrated that porcupines (Hystrix africaeaustralis) were present in the park from 1937 to 1998 but only recorded again between 2003 and 2020, leaving the period 1999-2002 without a confirmed record. However, field trips to MZNP by the Rhodes University Department of Zoology and Entomology began in 2001, and porcupines were sighted fairly regularly on night drives in 2001 and 2002. Thus, porcupines and nine other species (aardvark Orycteropus afer, springhare Pedetes capensis, ground squirrel Xerus inauris, chacma baboon Papio ursinus, vervet monkey Chlorocebus pygerythrus, aardwolf Proteles cristata, meerkat Suricata suricatta, yellow mongoose Cynictis penicillata and Cape grey mongoose Galerella pulverulenta) were recorded as being present between 1999 and 2002. I was confident that these 10 species could not be confused with any other mammal species.

To update and revise the checklist of mammals for MZNP, I assessed the reliability of the time-series data generated using the methods described above (Table 1). I adopted a conservative approach and only included a species on the revised checklist if a specimen had been reliably collected or observed or if there was photographic evidence of its presence in the park. Importantly, during the initial 27 year existence of the park (1937-1964), when the park was just $1712 \mathrm{Ha}$ in size, the only published account of the mammals that might be present was published by the renowned naturalist Jack Skead (1958). However, this publication is essentially a 'best guess' estimate of the mammals that could be found in the Cradock district as a whole and was not specific to the park (Skead 1958). Whilst Skead (1958) does rely on museum specimens to a limited extent, many of the species included in his publication were based on '.... distributional evidence from contiguous districts' and, in some cases, the diaries and notes of early European settlers. Although such data are valuable from an historical perspective, their reliability can be questionable, especially for non-charismatic and smaller species (Bernard \& Parker 2006). Nevertheless, for the sake of completeness, all of Skead's (1958) proposed records (except species which he deemed to be extinct at the time) were initially included in the generation of the time-series data (Table 1). However, if these records could not be corroborated by subsequent (reliable) records, they were not included in the revised checklist (Appendix 1).

\section{Results and discussion}

In its first 27 years of existence, it was estimated that a total of 60 mammalian species could have been present in MZNP (Table 1). Between 1965 and 1998, with the addition of several dedicated mammal surveys, this number increased to 62 (Table 1). However, the 1999 to 2002 period saw the number of mammals supposedly present in the park decline to just 35 (Table 1). However, this is likely an artefact of a lack of sampling and/or documented fieldwork in the park during this period as the number of mammal species present in the park increased to 63 between 2003 and 2020 (Table 1) when dedicated fieldwork was being conducted by the Rhodes University Department of Zoology and Entomology. Interestingly, despite the park increasing more than 12 times in size between 1965 and 2020, the overall number of mammal species present has stayed remarkably stable (Figure 2). However, the actual species composition present has changed substantially (Table 1). For example, many of the larger ungulate species were reintroduced and several surveys of the smaller mammals revealed previously unrecorded species (Table 1). The advent of passive infra-red camera traps to photograph medium and large species between 2003 and 2020 also likely contributed to the observed changes.

The revised and updated checklist for the park includes 68 species from 25 families representing 13 orders (Appendix 1 ). With 14 species present in the park, the bovidae is the best represented family, followed by the murid rodents (11 species; Appendix 1). As a group, the carnivores (hyaenidae, felidae, viverridae, canidae and mustelidae) are also fairly well represented (20 species) in the park (Appendix 1). All other families present in the park currently have less than three species represented (Appendix 1). Many of these remaining families represent the small, and arguably understudied, mammal groups (Appendix 1). I consider these 68 species to be the best current estimate of the mammal richness of the park. The species which I rejected from the final checklist are improbable and likely based on outdated distributional and ecological data or were originally mis-identified. I briefly discuss the 18 rejected species below. 
TABLE 1: The mammal species recorded at Mountain Zebra National Park between 1937 and 2020.

\begin{tabular}{|c|c|c|c|c|c|c|c|}
\hline Genus & Species & Common name & $1937-1964$ & $1965-1998$ & 1999-2002 & $2003-2020$ & References \\
\hline Amblysomus & hottentotus & Hottentot golden mole & - & $x$ & - & $x$ & $1,2,3$ \\
\hline Elephantulus & intufi & Bushveld elephant shrew & $x$ & - & - & - & 4 \\
\hline Elephantulus & rupestris & Western rock elephant shrew & $x$ & $x$ & - & $x$ & $2,3,4,5,6$ \\
\hline Macroscelides & proboscideus & Round-eared elephant shrew & $x$ & - & - & - & 4 \\
\hline Orycteropus & afer & Aardvark & $x$ & $x$ & $x$ & $x$ & $2,4,5,6$ \\
\hline Procavia & capensis & Rock hyrax & $x$ & $x$ & $x$ & $x$ & $2,4,5,7,8,9,10,11,12,13,14$ \\
\hline Lepus & capensis & Cape hare & $x$ & $\mathrm{x}$ & - & $x$ & $1,2,4,6,7$ \\
\hline Pronolagus & rupestris & Smith's red rock rabbit & $\mathrm{x}$ & $\mathrm{x}$ & - & $x$ & $1,2,4,9,10,12,14$ \\
\hline Cryptomus & hottentotus & African mole-rat & $x$ & $x$ & - & - & $2,4,5,7$ \\
\hline Hystrix & africaeaustralis & Porcupine & $x$ & $\mathrm{x}$ & $x$ & $x$ & $2,4,5,6,7,15$ \\
\hline Pedetes & capensis & Springhare & $x$ & $x$ & $x$ & $x$ & $2,4,5,6,9,12$ \\
\hline Xerus & inauris & Ground squirrel & $x$ & $x$ & $x$ & $x$ & $2,4,5,6,13$ \\
\hline Graphiurus & ocularis & Spectacled dormouse & $x$ & $x$ & - & - & 2,4 \\
\hline Rhabdomys & pumilio & Striped fieldmouse & $x$ & $x$ & $x$ & $x$ & $2,4,5,7,12,17,18,19$ \\
\hline Mus & minutoides & Pygmy mouse & $x$ & - & $x$ & $x$ & $4,18,20$ \\
\hline Mastomys & natalensis & Natal multimammate mouse & $x$ & $x$ & $x$ & $x$ & $2,4,5,7,16,18,19$ \\
\hline Rattus & norvegicus & Brown mouse & - & $\mathrm{x}$ & - & - & 2 \\
\hline Michaelamys & namaquensis & Namaqua rock mouse & $x$ & $x$ & $x$ & $x$ & $2,4,5,12,18,19,20$ \\
\hline Michaelamys & granti & Grant's rock mouse & - & $x$ & - & - & 2 \\
\hline Otomys & irroratus & Vlei rat & $x$ & $x$ & - & $x$ & $2,4,19,20,21$ \\
\hline Otomys & sloggetti & Sloggett's ice rat & $x$ & - & - & $x$ & 4,20 \\
\hline Otomys & unisulcatus & Bush Karoo rat & $x$ & $x$ & - & - & $2,4,7,12$ \\
\hline Saccostomus & campestris & Pouched mouse & $x$ & $x$ & $x$ & $x$ & $2,4,5,7,12,16,18,19$ \\
\hline Dendromus & melanotis & Grey climbing mouse & - & - & - & $x$ & 20 \\
\hline Steatomys & pratensis & Fat mouse & $x$ & - & - & - & 4 \\
\hline Malacothrix & typica & Gerbil mouse & $x$ & - & - & - & 4 \\
\hline Desmodillus & auricularis & Short-tailed gerbil & $x$ & $x$ & - & - & $2,4,5$ \\
\hline Chlorocebus & pygerythrus & Vervet monkey & $x$ & $x$ & $x$ & $x$ & $2,4,5,6,13$ \\
\hline Myosorex & varius & Forest shrew & - & $x$ & - & $x$ & $1,2,20$ \\
\hline Crocidura & cyanea & Reddish-grey musk shrew & $x$ & - & - & - & 4 \\
\hline Erinaceus & frontalis & Hedgehog & $x$ & $x$ & - & $x$ & $2,4,22$ \\
\hline Eidolon & helvum & Straw-coloured fruit bat & $x$ & - & - & - & 4 \\
\hline Rhinolophus & clivosus & Geoffroy's horseshoe bat & - & $x$ & - & - & 2 \\
\hline Taphozous & mauritianus & Mauritian tomb bat & $x$ & - & - & - & 4 \\
\hline Nycteris & thebaica & Egyptian slit-faced bat & - & - & - & $x$ & 23,24 \\
\hline Tadarida & aegyptiaca & Egyptian free-tailed bat & $x$ & $x$ & - & $x$ & $2,4,23,24$ \\
\hline Neoromicia & capensis & Cape serotine bat & $x$ & $x$ & - & $x$ & $2,7,7,23,24$ \\
\hline Miniopterus & natalensis & Natal long-fingered bat & $x$ & - & - & - & 4 \\
\hline Proteles & cristata & Aardwolf & $x$ & $x$ & $x$ & $x$ & $2,4,5,6,13$ \\
\hline Parahyaena & brunnea & Brown hyaena & - & - & - & $x$ & $6,13,25$ \\
\hline Acinonyx & jubatus & Cheetah & - & - & - & $x$ & $6,13,25$ \\
\hline Panthera & leo & Lion & - & - & - & $x$ & 6,25 \\
\hline Panthera & pardus & Leopard & $x$ & - & - & - & 4 \\
\hline Caracal & caracal & Caracal & $x$ & $\mathrm{x}$ & - & $\mathrm{x}$ & $2,4,6,12,15$ \\
\hline Felis & silvestris & African wild cat & $\mathrm{x}$ & $\mathrm{x}$ & - & $x$ & $2,4,14$ \\
\hline Felis & nigripes & Black-footed cat & $x$ & $x$ & - & $x$ & $2,4,5,6$ \\
\hline Genetta & genetta & Small-spotted genet & $x$ & $x$ & - & $x$ & $1,2,4,6$ \\
\hline Genetta & tigrina & Large-spotted genet & - & - & - & $x$ & 6 \\
\hline Suricata & suricatta & Meerkat & $x$ & $x$ & $x$ & $x$ & $2,4,5,6,13$ \\
\hline Cynctis & penicillata & Yellow mongoose & $x$ & $x$ & $x$ & $x$ & $2,4,5,6,7,13,26$ \\
\hline Galerella & pulverulenta & Cape grey mongoose & $x$ & $\mathrm{x}$ & $x$ & $x$ & $2,4,5,6,9,10,13$ \\
\hline Atilax & paludinosus & Marsh mongoose & $x$ & $x$ & - & $x$ & $1,2,4,6,26$ \\
\hline Ichneumia & albicaudatus & White-tailed mongoose & $x$ & - & - & - & 4 \\
\hline Otocyon & megalotis & Bat-eared fox & $x$ & $x$ & $x$ & $x$ & $2,4,6$ \\
\hline Vulpes & chama & Cape fox & $x$ & $x$ & - & $x$ & $2,4,6$ \\
\hline
\end{tabular}


TABLE 1 (Continues...): The mammal species recorded at Mountain Zebra National Park between 1937 and 2020.

\begin{tabular}{|c|c|c|c|c|c|c|c|}
\hline Genus & Species & Common name & $1937-1964$ & 1965-1998 & 1999-2002 & 2003-2020 & References \\
\hline Hydrictis & maculicollis & Spotted neck otter & $x$ & - & - & - & 4 \\
\hline Mellivora & capensis & Honey badger & $x$ & - & - & $x$ & 4,14 \\
\hline Poecilogale & albinucha & White-naped weasel & $x$ & $x$ & - & - & $1,2,4$ \\
\hline Ictonyx & striatus & Striped polecat & $x$ & $x$ & - & $x$ & $2,4,5,6$ \\
\hline Diceros & bicornis & Black rhinoceros & - & - & $x$ & $x$ & $6,13,25,27$ \\
\hline Equus & zebra zebra & Cape mountain zebra & $x$ & $x$ & $x$ & $x$ & $2,4,6,8,11,13,27,28$ \\
\hline Equus & quagga & Plains zebra & - & $x$ & $x$ & $x$ & 6,27 \\
\hline Potamochoerus & larvatus & Bushpig & - & $x$ & - & $x$ & $1,2,6$ \\
\hline Phacochoerus & africanus & Warthog & - & - & - & $x$ & $6,27,29$ \\
\hline Syncerus & caffer & Buffalo & - & - & $x$ & $x$ & $6,13,25,27$ \\
\hline Tragelaphus & strepsiceros & Greater kudu & - & $x$ & $x$ & $x$ & $1,2,6,11,13,27,28$ \\
\hline Tragelaphus & scriptus & Bushbuck & - & $x$ & - & - & 1,2 \\
\hline Tragelaphus & oryx & Eland & - & $x$ & $x$ & $x$ & $2,6,8,11,12,13,27,28$ \\
\hline Connochaetes & gnou & Black wildebeest & - & $x$ & $x$ & $x$ & $2,6,8,11,12,13,27,28$ \\
\hline Damaliscus & pygargus phillipsi & Blesbok & - & $x$ & $x$ & $x$ & $2,6,8,11,13,27,28$ \\
\hline Oryx & gazella & Gemsbok & - & $x$ & $x$ & $x$ & $6,8,25,27,28$ \\
\hline Sylvicapra & grimmia & Common duiker & $x$ & $x$ & $x$ & $x$ & $2,4,6,8,9,11,13,27,28$ \\
\hline Redunca & arundinum & Common reedbuck & - & $x$ & - & - & 8 \\
\hline Redunca & fulvorufula & Mountain reedbuck & $x$ & $x$ & $x$ & $x$ & $2,4,6,8,9,10,11,12,13,27,28$ \\
\hline Pelea & capreolus & Grey rhebok & $x$ & $x$ & $x$ & $x$ & $1,2,4,6,27,28$ \\
\hline Antidorcas & marsupialis & Springbok & $x$ & $x$ & $x$ & $x$ & $2,4,6,8,9,10,11,12,13,27,28,30$ \\
\hline Raphicerus & campestris & Steenbok & $x$ & $x$ & $x$ & $x$ & $2,4,6,8,9,10,11,13,27$ \\
\hline Oreotragus & oreotragus & Klipspringer & $x$ & $x$ & $x$ & $x$ & $4,6,8,11,27,28$ \\
\hline Total & - & - & 60 & 62 & 35 & 63 & - \\
\hline
\end{tabular}

Sources: ${ }^{1}$ Grobler and Bronkhorst (1981); ${ }^{2}$ Grobler and Hall-Martin (1982); ${ }^{3}$ Craig et al. (2011); ${ }^{4}$ Skead (1958); ${ }^{5}$ Nel and Pretorius (1971); ${ }^{6}$ Comley (2016); ${ }^{7}$ De Graaff and Nel (1970); ${ }^{8}$ Penzhorn (1971); ${ }^{9}$ Grobler (1981); ${ }^{10}$ Moolman (1984); ${ }^{11}$ Horak and Fourie (1986); ${ }^{12}$ Horak et al. (1991); ${ }^{13}$ Craig et al. (2010); ${ }^{14}$ Bissett (2012); ${ }^{15}$ Craig et al. (2009); ${ }^{16}$ Morris (2010); ${ }^{17} \mathrm{Jackson}$ and Bernard (2005); ${ }^{18}$ Whittington-Jones et al. (2008); ${ }^{19}$ Craig et al. (2011); ${ }^{20}$ Kok et al. (2012); ${ }^{21}$ Stuart (1987); ${ }^{22}$ Craig Williams, Section Ranger, Pers. Comm. ${ }^{23}$ Bernard, Craig and Hulley (2005); ${ }^{24}$ Parker, Bissett and Craig (2014); ${ }^{25}$ SANParks (2016); ${ }^{26}$ Du Toit (1980); ${ }^{27}$ Bissett et al. (2019); ${ }^{28}$ Van der Walt (1980); ${ }^{29}$ Parker et al. (2013); ${ }^{30}$ De Graaff and Penzhorn (1976).

Note: Please see the full reference list of the article, Parker, D.M., 2021, 'Mammals in the mountains: An historical review and updated checklist of the mammals of the Mountain Zebra National Park', Koedoe 63(1), a1683. https://doi.org/10.4102/koedoe.v63i1.1683, for more information.

The genus, species and common names are listed along with the period(s) in which the species was recorded (denoted by an X), and the associated references for each species.

\section{Rejected species}

\section{Bushveld elephant shrew (Elephantulus intufi)}

The inclusion of this species was based on what was believed to be the most plausible distribution at the time (Skead 1958). As no additional specimens have been collected, or verifiable sightings made since its initial inclusion, I rejected it from the updated checklist of MZNP.

\section{Round-eared elephant shrew (Macroscelides proboscideus)}

The inclusion of this species was based on what was believed to be the most plausible distribution at the time (Skead 1958). As no additional specimens have been collected, or verifiable sightings made since its initial inclusion, I rejected it from the updated checklist of MZNP.

\section{Spectacled dormouse (Graphiurus ocularis)}

Like the previous two species, the spectacled dormouse appears to have been included based on what was believed to be the most plausible distribution at the time (Skead 1958). Although the first published field guide for the park lists the species as being present, it provides no corroborating evidence for its listing (Grobler \& Hall-Martin 1982). Certainly, none of the more comprehensive small mammal surveys conducted at MZNP have recorded the species (De Graaff \& Nel 1970; Kok, Parker \& Barker 2012; Nel \& Pretorius 1971). As such, I rejected it from the updated checklist of MZNP.

\section{Brown mouse (Rattus norvegicus)}

The first published field guide for the park lists this alien species as being present, but without any corroborating evidence (Grobler \& Hall-Martin 1982). As none of the more comprehensive small mammal surveys conducted at MZNP have recorded the species (De Graaff \& Nel 1970; Kok et al. 2012; Nel \& Pretorius 1971), I rejected it from the updated checklist of MZNP.

\section{Grant's rock mouse (Michaelamys granti)}

Similarly, Grobler and Hall-Martin (1982) list Grant's rock mouse as being present without any supporting evidence. Since none of the more comprehensive small mammal surveys conducted at MZNP have recorded the species (De Graaff \& Nel 1970; Kok et al. 2012; Nel \& Pretorius 1971), I rejected it from the updated checklist of MZNP.

\section{Fat mouse (Steatomys pratensis)}

The inclusion of this species was based on what was believed to be the most plausible distribution at the time (Skead 1958). As no additional specimens have been collected, or verifiable sightings made since its initial inclusion, I rejected it from the updated checklist of MZNP.

\section{Gerbil mouse (Malacothrix typica)}

The inclusion of this species was based on what was believed to be the most plausible distribution at the time (Skead 1958). 


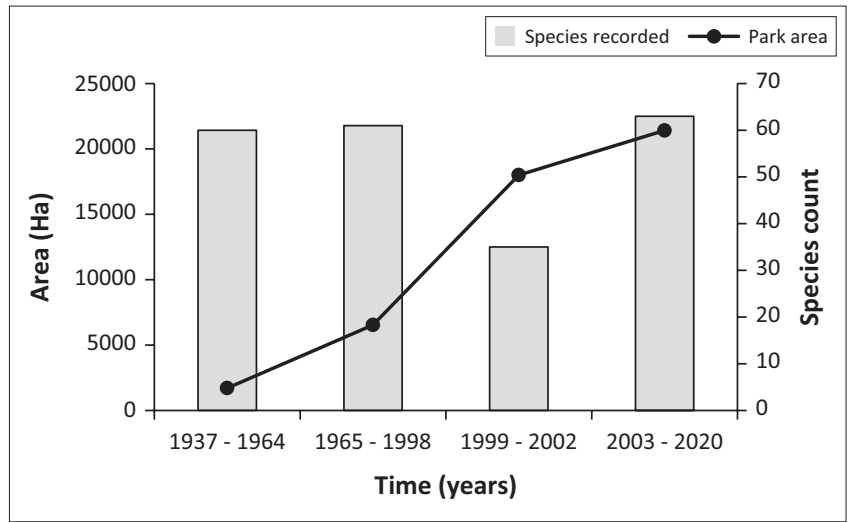

FIGURE 2: The four periods of park expansion for the Mountain Zebra National Park, Eastern Cape, South Africa between 1937 and 2020. The total number of mammal species recorded during each period (grey bars) is also shown. The solid line denotes the cumulative increase in park area (hectares) over time.

As no additional specimens have been collected, or verifiable sightings made since its initial inclusion, I rejected it from the updated checklist of MZNP.

\section{Reddish-grey musk shrew (Crocidura cyanea)}

The inclusion of this species was based on what was believed to be the most plausible distribution at the time (Skead 1958). As no additional specimens have been collected, or verifiable sightings made since its initial inclusion, I rejected it from the updated checklist of MZNP.

\section{Straw-coloured fruit bat (Eidolon helvum)}

The inclusion of this species was based on what was believed to be the most plausible distribution at the time (Skead 1958). As no additional specimens have been collected, or verifiable sightings made since its initial inclusion, I rejected it from the updated checklist of MZNP.

\section{Geoffroy's horseshoe bat (Rhinolophus clivosus)}

This species is listed in the first field guide for the park (Grobler \& Hall-Martin 1982). Although no corroborating evidence is supplied in the guide, horseshoe bats are relatively easily distinguished from other insectivorous bats based on their characteristic nose-leaf patterns (Monadjem et al. 2020). In addition, Hans Grobler was the resident biologist in the MZNP at the time and he could easily have observed horseshoe bats roosting in the cave or culvert. However, despite Geoffroy's horseshoe bat (Rhinolophus clivosus) being broadly distributed across the Eastern Cape (Monadjem et al. 2020), without any corroborating morphometric or echolocatory evidence, it could be confused with at least one other horseshoe bat species (Monadjem et al. 2020). As such, I rejected it from the updated checklist of MZNP.

\section{Mauritian tomb bat (Taphozous mauritianus)}

The inclusion of this species was based on what was believed to be the most plausible distribution at the time (Skead 1958). As no additional specimens have been collected, or verifiable sightings made since its initial inclusion, I rejected it from the updated checklist of MZNP.

\section{Natal long-fingered bat (Miniopterus natalensis)}

The inclusion of this species was based on what was believed to be the most plausible distribution at the time (Skead 1958). As no additional specimens have been collected, or verifiable sightings made since its initial inclusion, I rejected it from the updated checklist of MZNP.

\section{Leopard (Panthera pardus)}

Skead (1958) was the only author who believed that leopards could be present in the MZNP. Despite photographic evidence of leopards elsewhere in the Karoo, leopards have never been reliably recorded in the MZNP where numerous camera trapping surveys have been (and continue to be) conducted. As such, I rejected it from the updated checklist of MZNP.

\section{White-tailed mongoose (Ichneumia albicaudatus)}

The inclusion of this species was based on what was believed to be the most plausible distribution at the time (Skead 1958). As no additional specimens have been collected, or verifiable sightings made since its initial inclusion, I rejected it from the updated checklist of MZNP.

\section{Spotted-neck otter (Hydrictis maculicollis)}

The inclusion of this species was based on what was believed to be the most plausible distribution at the time (Skead 1958). As no additional specimens have been collected, or verifiable sightings made since its initial inclusion, I rejected it from the updated checklist of MZNP.

\section{Plains zebra (Equus quagga)}

Plains zebra were intentionally introduced into MZNP in 1998 (SANParks 2016). As plains zebra are known to hybridise with Cape mountain zebras, producing fertile hybrids (Kotze et al. 2017), plains zebras resembling the extinct quagga were introduced in an attempt to recreate the quagga through selective breeding. However, in 2014, SANParks discontinued the programme and removed all plains zebra individuals from the park. By 2015, plains zebra were no longer recorded during annual aerial game censuses and are believed to have been eradicated from the park (Bissett et al. 2019). As such, I rejected it from the updated checklist of MZNP.

\section{Common reedbuck (Redunca arundinum)}

Common reedbuck (Redunca arundinum) were also intentionally introduced into MZNP in the 1960s (Penzhorn 1971). However, Grobler and Bronkhorst (1981) note that they failed to thrive and by 1981 were no longer present in the park. As such, I rejected it from the updated checklist of MZNP.

\section{Re-introductions, immigrations and introductions}

At the time of proclamation (1937), the only larger herbivores believed to be present in the park were Cape mountain zebra, klipspringer (Oreotragus oreotragus), steenbok (Raphicerus 
campestris), common duiker (Sylvicapra grimmia), grey rhebok (Pelea capreolus), mountain reedbuck (Redunca fulvorufula) and rock hyrax (Procavia capensis) (Grobler \& Bronkhorst 1981; Grobler \& Hall-Martin 1982; Penzhorn 1971). The first ungulate re-introduction occurred in the 1940s when a small group of springbok (Antidorcas marsupialis) were translocated from a farm near Bedford (Penzhorn 1971). Re-introductions of blesbok (Damaliscus pygargus phillipsi), black wildebeest (Connochaetes gnou), red hartebeest (Alcelaphus buselaphus), gemsbok (Oryx gazella) and eland (Tragelaphus oryx) followed in the 1960s (Grobler \& Hall-Martin 1982; Novellie \& Knight 1994; Penzhorn 1971). All of these ungulate re-introductions were successful except for that of the gemsbok. The entire reintroduced gemsbok population was removed in 1981 because 'they were not doing well' (Grobler \& Bronkhorst 1981). The reason for their failure to thrive is likely because of the poor habitat available to the animals at the time. Till the early 2000s, only the more mountainous, sourveld region of the park was available to the animals, and the overall poor palatability of the grass species in this section, and greater climatic fluctuations in the mountains, could have negatively affected the gemsbok population (Grobler \& Hall-Martin 1982). However, with the expansion of the park in the early 2000s, the additional 'sweeter' veld became available (Brown \& Bezuidenhout 2005), and a second re-introduction of gemsbok to the park in 2004 was much more successful. Gemsbok numbers are now in excess of 200 individuals and they are very seldom sighted in the southern (more mountainous) section of the park (Bissett et al. 2019). More recent, large mammal re-introductions include buffaloes (Syncerus caffer) in 1997, black rhinoceros (Diceros bicornis) in 2002, cheetah (Acinonyx jubatus) in 2007, brown hyaena (Parahyaena brunnea) in 2008 and lion (Panthera leo) in 2013 (Bissett et al. 2019; SANParks 2016). All of these species were re-introduced in accordance with the park's objective of restoring the historical diversity of large mammals of the region (SANParks 2016) and have been successful (Bissett et al. 2019).

The late 1970s saw the natural immigration of bushpig (Potomochoerus larvatus), greater kudu (Tragelaphus strepsiceros) and bushbuck (Tragelaphus scriptus) into the park (Grobler \& Bronkhorst 1981). The only other non-volant mammal which is believed to have naturally immigrated into the park is the extralimital warthog (Phacochoerus africanus) in approximately 2012 (Parker, Bissett \& Craig 2013).

Although thought to be present in the region at the time of establishment of the park (Skead 1958), it was not until mid1979 that two African clawless otters (Aonyx capensis) escaped from a temporary cage on the Babylons Toren section of the park (Grobler \& Bronkhorst 1981). Grobler and Bronkhorst (1981) speculated that as the pair was a male and a female that perhaps they would establish themselves in the park. However, it was not until one of the first intensive camera trapping surveys of the park that African clawless otters were reliably recorded again (Figure 3; Comley 2016).

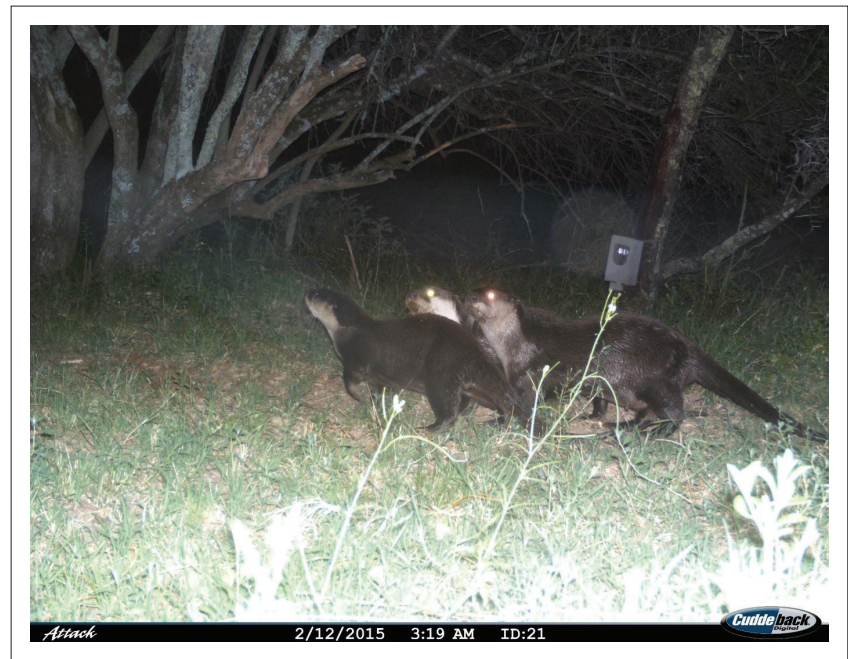

Source: Comley, J., 2016, 'Population assessment and feeding ecology of brown hyaenas (Hyaena brunnea) in Mountain Zebra National Park, Eastern Cape, South Africa', MSc thesis, Department of Zoology and Entomology, Rhodes University, Grhamstown.

FIGURE 3: Three African clawless otters (Aonyx capensis) photographed on camera trap during a brown hyaena (Parahyaena brunnea) population assessment (Comley 2016) in the Mountain Zebra National Park, Eastern Cape, South Africa. Permission to use the image granted by Jessica Comley.

\section{Taxonomic conundrums and future research priorities}

The number of species within the genus Lepus has been a matter of debate amongst taxonomists for some time (Skinner \& Chimimba 2005). Despite some regional differences in skull and ear length, it is now accepted that the only two species to occur in South Africa are L. saxatilis and L. capensis (Skinner \& Chimimba 2005). Both of these species have been reliably collected as specimens in MZNP (Grobler \& Bronkhorst 1981; Nel \& Pretorius 1971). However, all subsequent records have been through direct observations or camera trap photographs. As the most reliable way to distinguish between the two species is by comparison of the incisors (Skinner \& Chimimba 2005), direct observations and camera trap photographs of hares, with potentially variable pelage, should be interpreted with caution. Thus, either the collection of museum specimens or the sampling of DNA from captured specimens should be a future research priority.

Cryptic speciation amongst the laminate toothed rats (family Muridae: subfamily Murinae: tribe Otomyini), to which the vlei (Otomys irroratus), bush Karoo (O. unisulcatus) and Sloggett's ice rat (O. sloggetti) belong, is common, especially in mountainous habitats (Taylor et al. 2019). In fact, recent taxonomic work has demonstrated that $O$. irroratus senso lato can be confused morphologically with at least one other cooccurring species O. karoensis (Taylor et al. 2019). As such, I recommend that the specific assignment of the three laminate toothed rats putatively present in MZNP be verified through the collection of specimens for morphological and genetic analyses.

Notwithstanding the taxonomic conundrums that require resolution, it is clear that there has been unequal surveying and documenting of the mammals present within the MZNP 
over time. There has clearly been a bias towards the larger, more charismatic species and less of a focus on the small, more cryptic mammal groups (but see De Graaff \& Nel 1970; Kok et al. 2012; Nel \& Pretorius 1971). As such, I believe that a concerted effort should be made to comprehensively sample the MZNP for golden moles, elephant shrews, rodent moles, gerbils and bats. Whilst the sampling of the fossorial small mammals can be challenging and labour intensive, recent technological advances in acoustic technology make the sampling of echolocating bats (a notoriously difficult mammal group to sample) much more feasible (Parker \& Bernard 2019).

\section{Conclusion}

Like most of the initial national parks gazetted in South Africa, the MZNP was initially proclaimed to protect the survival of just one species, the mountain zebra. However, as time has progressed, and conservation priorities have changed (SANParks 2016), the conservation footprint of the MZNP has been expanded and the diversity of mammals receiving formal protection has been increased. Whilst the updated and revised checklist presented here is the most comprehensive current list available, I am confident that with targeted survey work, additional mammal species will be added.

\section{Acknowledgements}

I would like to thank my colleagues, Ric Bernard, Adrian Craig and Chris Brown, for getting much of the more recent mammal survey work off the ground in the late 1990s and early 2000s. Thanks are also because of the park managers and section rangers at MZNP for their support of the work. Thank you to Paddy Gordon, Johan de Klerk, Phumla Mzazi, Lesley-Ann Brown, Robyn Woods, Craig Williams, Megan Taplin and Greg Bond. Additionally, thank you to all the students, colleagues and other 'hangers on' who assisted in the field over the years. Special mention must be made of Charlene Bissett for all the glorious hours in the field, the fire-side chats (and arguments) and her critical and constructive eye on the manuscript. Finally, I acknowledge Rhodes University for its financial assistance.

\section{Competing interests}

The author declares that he has no financial or personal relationships that may have inappropriately influenced him in writing this article.

\section{Author's contributions}

D.M.P. contributed solely to this work.

\section{Ethical considerations}

This article followed all ethical standards for research without direct contact with human or animal subjects.

\section{Funding information}

This research received no specific grant from any funding agency in the public, commercial or not-for-profit sectors.

\section{Data availability}

The data that support the findings of this study are available from the corresponding author, D.M.P., upon reasonable request.

\section{Disclaimer}

The views and opinions expressed in this article are those of the authors and do not necessarily reflect the official policy or position of any affiliated agency of the author.

\section{References}

Bernard, R.T.F., Craig, A.J.F.K. \& Hulley, P.E., 2005, The effects of past land use on biodiversity, Mountain Zebra National Park, Annual progress report to SANParks, Department of Zoology and Entomology, Rhodes University, Grahamstown.

Bernard, R.T.F. \& Parker, D.M., 2006, 'The use of archaeological and ethnographical information to supplement the historical record of the distribution of large mammalian herbivores', South African Journal of Science 102, 117-119.

Bezuidenhout, H. \& Brown, L.R., 2008, 'Vegetation description of the Doornhoek section of the Mountain Zebra National Park (MZNP), South Africa', Koedoe 50(1), 32-41. https://doi.org/10.4102/koedoe.v50i1.142

Bissett, C., 2012, Space use and feeding ecology of large carnivores in small, fenced reserves: Case study of cheetahs and brown hyaenas in Mountain Zebra National Park, Annual progress report to SANParks, Department of Zoology and Entomology, Rhodes University, Grahamstown.

Bissett, C., Ferreira, S., Ramoelo, A., Bezuidenhout, H., Januarie, R. \& Raselabe, M., 2019, Mountain Zebra National ark herbivore off-take recommendations 2019: An integrated approach combining local knowledge with data derived from animal census, herbivore models and satellite imagery, Internal Report 30/2019, Scientific Services, SANParks, Pretoria.

Brown, L.R. \& Bezuidenhout, H., 2005, 'A vegetation description and classification of the farms Ingleside and Welgedacht in the Mountain Zebra National Park, Eastern Cape', Koedoe 48(2), 23-42. https://doi.org/10.4102/koedoe.v48i2.92

Comley, J., 2016, 'Population assessment and feeding ecology of brown hyaenas (Hyaena brunnea) in Mountain Zebra National Park, Eastern Cape, South Africa', MSc thesis, Department of Zoology and Entomology, Rhodes University, Grahamstown.

Craig, A.J.F.K., Hulley, P.E. \& Parker, D., 2005, 'A re-assessment of the avifauna of the Mountain Zebra National Park', Koedoe 48(1), 95-113. https://doi.org/10.4102/ koedoe.v48i1.169

Craig, A.J.F.K., Parker, D.M., Hulley, P.E. \& Bernard, R.T.F., 2009, The effects of past land use on biodiversity, Mountain Zebra National Park, Annual progress report to SANParks, Department of Zoology and Entomology, Rhodes University, Grahamstown.

Craig, A.J.F.K., Parker, D.M., Hulley, P.E. \& Bernard, R.T.F., 2010, The effects of past land use on biodiversity, Mountain Zebra National Park, Annual progress report to SANParks, Department of Zoology and Entomology, Rhodes University, Grahamstown.

Craig, A.J.F.K., Parker, D.M., Hulley, P.E. \& Bernard, R.T.F., 2011, The effects of past land use on biodiversity, Mountain Zebra National Park, Annual progress report to SANParks, Department of Zoology and Entomology, Rhodes University, Grahamstown.

De Bondi, N., White, J.G., Stevens, M. \& Cooke, R., 2010, 'A comparison of the effectiveness of camera trapping and live-trapping for sampling terrestrial small mammal communities', Wildlife Research 37(6), 456-465. https://doi. org/10.1071/WR10046

De Graaff, G. \& Nel, J.A.J., 1970, 'Notes on the smaller mammals of the Eastern Cape National Parks', Koedoe 13(1), 147-149. https://doi.org/10.4102/koedoe.v13i1.736

De Graaff, G. \& Penzhorn, B.L., 1976, 'The reintroduction of springbok Antidorcas marsupialis into South African National Parks - A documentation', Koedoe 19(1), 75-82. https://doi.org/10.4102/koedoe.v19i1.1184

Du Toit, C.F., 1980, 'The yellow mongoose Cynictis penicillata and other small carnivores in the Mountain Zebra National Park', Koedoe 23(1), 179-184. https:// doi.org/10.4102/koedoe.v23i1.645

Grobler, J.H., 1981, 'Feeding behaviour of the caracal Felis caracal Shreber 1776 in the Mountain Zebra National Park', South African Journal of Zoology 16(4), 259-262. https://doi.org/10.1080/02541858.1981.11447764

Grobler, J.H. \& Bronkhorst, P.J., 1981, 'Additions and amendments to the bird and mammal lists of the Mountain Zebra National Park', Koedoe 24, 199-203. https:// doi.org/10.4102/koedoe.v24i1.630 
Grobler, H. \& Hall-Martin, A., 1982, A guide to the Mountain Zebra National Park, National Parks Board of Trustees, Pretoria.

Horak, I.G. \& Fourie, L.J., 1986, 'Parasites of domestic and wild animals in South Africa. XIX. Ixodid ticks and fleas on rock dassies (Procavia capensis) in the Mountain Zebra National Park', Onderstepoort Journal of Veterinary Research 53(2), 123-126.

Horak, I.G., Fourie, L.J., Novellie, P.A. \& Williams, E.J., 1991, 'Parasites of domestic and wild animals in South Africa. XXVI. The mosaic of ixodid tick infestations on birds and mammals in the Mountain Zebra National Park', Onderstepoort Journal of Veterinary Research 58(3), 125-136.

Jackson, C. \& Bernard, R.T.F., 2005, 'Effects of supplementary food on the winte inhibition of reproduction in male and female four-striped field mice (Rhabdomy pumilio)', Reproduction, Fertility and Development 17(4), 393-400. https://doi. org/10.1071/RD04134

Kok, A.D., Parker, D.M. \& Barker, N.P., 2012, 'Life on high: The diversity of small mammals at high altitude in South Africa', Biodiversity and Conservation 21(11) 2823-2843. https://doi.org/10.1007/s10531-012-0340-0

Kotze, A., Zimmerman, D., Dalton, D.L., Mnisi, C., Taplin, M., Novellie, P. et al., 2017 'Hiding in plain sight: Evidence of hybridization between Cape mountain zebra (Equus zebra zebra) and plains zebra (Equus quagga burchelli)', African Journal of Wildlife Research 47(1), 59-64. https://doi.org/10.3957/056.047.0059

Monadjem, A., Taylor, P.J., Cotterill, F.P.D. \& Schoeman, M.C., 2020, Bats of southern and central Africa: A biogeographic and taxonomic synthesis, Wits University Press, Johannesburg.

Moolman, L.C., 1984, 'n Vergelyking van die voedingsgewoontes van die rooikat Felis caracal binne en buite die Bergkwagga Nasionale Park', Koedoe 27(1), 121-129. https://doi.org/10.4102/koedoe.v27i1.554

Morris, D., 2010, 'The effects of land use change on the small mammal communities of the Mountain Zebra National Park, Eastern Cape, South Africa', Honours thesis, Department of Zoology and Entomology, Rhodes University.

Mucina, L., Rutherford, M.C., Palmer, A.R., Milton, S.J., Scott, L., Lloyd, J.W. et al., 2006 'Nama-Karoo Biome', in L. Mucina \& M.C. Rutherford (eds.), The vegetation of South Africa, Lesotho and Swaziland, pp. 325-347, South African National Biodiversity Institute, Pretoria.

Nel, J.A.J. \& Pretorius, J.J.L., 1971, 'A note on the smaller mammals of the Mountain Zebra National Park', Koedoe 14, 99-110. https://doi.org/10.4102/koedoe.v14i1.719
Novellie, P.A. \& Knight, M., 1994, 'Repatriation and translocation of ungulates into South African National Parks: An assessment of past attempts', Koedoe 37(1), 115-119. https://doi.org/10.4102/koedoe.v37i1.328

Parker, D.M. \& Bernard, R.T.F., 2019, 'The use of acoustic detectors for assessing bat species richness and functional activity in a South African National Park', Mammalia 83(1), 53-63. https://doi.org/10.1515/mammalia-2017-0055

Parker, D.M., Bissett, C. \& Craig, A.J.F.K., 2013, The effects of past land use on biodiversity, Mountain Zebra National Park, Mid-year fieldtrip report to SANParks, Department of Zoology and Entomology, Rhodes University, Grahamstown.

Parker, D.M., Bissett, C. \& Craig, A.J.F.K., 2014, The effects of past land use on biodiversity, Mountain Zebra National Park, Mid-year fieldtrip report to SANParks, Department of Zoology and Entomology, Rhodes University, Grahamstown.

Penzhorn, B.L., 1971, 'A summary of the reintroduction of ungulates into South African National Parks (to December 1970)', Koedoe 14(1), 145-159. https://doi. org/10.4102/koedoe.v14i1.725

SANParks, 2016, Mountain Zebra National Park: Park Management Plan for the period 2016-2026, South African National Parks, Pretoria.

Skead, C.J., 1958, 'Mammals of the Uitenhage and Cradock districts C.P. in recent times', Koedoe 1(1), 19-59. https://doi.org/10.4102/koedoe.v1i1.864

Skinner, J.D. \& Chimimba, C.T., 2005, The mammals of the Southern African subregion, Cambridge University Press, Cape Town.

Stuart, C.T., 1987, 'The vlei rat Otomys irroratus recorded in the Mountain Zebra National Park', Koedoe 30, 167. https://doi.org/10.4102/koedoe.v30i1.511

Taylor, P.J., Kearney, T., Dalton, D.L., Chakona, G., Kelly, C.M.R. \& Barker, N.P., 2019, 'Biomes, geology and past climate drive speciation of laminate-toothed rats on South African mountains (Murinae: Otomys)', Zoological Journal of the Linnean Society 189(3), 1046-1066. https://doi.org/10.1093/zoolinnean/ zlz134

Van der Walt, P.T., 1980, 'A phytosociological reconnaissance of the Mountain Zebra National Park', Koedoe 23(1), 1-32. https://doi.org/10.4102/koedoe. v23i1.632

Whittington-Jones, G.M., Bernard, R.T.F. \& Parker, D.M., 2008, 'Bushclumps as refugia for small mammals in two Eastern Cape Conservation areas', African Zoology 43(2), 273-276. https://doi.org/10.1080/15627020.2008.11657244 


\section{Appendix 1}

TABLE 1-A1: The updated (2020) checklist of 68 mammal species in the Mountain Zebra National Park, Eastern Cape, South Africa. See text for details on the criteria used for inclusion.

\begin{tabular}{|c|c|c|c|c|}
\hline$\overline{\text { Order }}$ & Family & Genus & Species & $\overline{\text { Common name }}$ \\
\hline Afrosoricida & Chrysochloridae & Amblysomus & Hottentotus & $\begin{array}{l}\text { Hottentot } \\
\text { golden mole }\end{array}$ \\
\hline Macroscelidae & Macroscelididae & Elephantulus & Rupestris & $\begin{array}{l}\text { Western rock } \\
\text { elephant shrew }\end{array}$ \\
\hline Tubulidentata & Orycteropodidae & Orycteropus & Afer & Aardvark \\
\hline Hyracoidea & Procaviidae & Procavia & Capensis & Rock hyrax \\
\hline Lagomorpha & Leporidae & Lepus & Saxatilis & Scrub hare \\
\hline- & - & Lepus & Capensis & Cape hare \\
\hline- & - & Pronolagus & Rupestris & $\begin{array}{l}\text { Smith's red rock } \\
\text { rabbit }\end{array}$ \\
\hline Rodentia & Bathyergidae & Cryptomus & Hottentotus & $\begin{array}{l}\text { African mole- } \\
\text { rat }\end{array}$ \\
\hline- & Hystricidae & Hystrix & Africaeaustralis & Porcupine \\
\hline- & Peditidae & Pedetes & Capensis & Springhare \\
\hline- & Sciuridae & Xerus & Inauris & Ground squirrel \\
\hline- & Myoxidae & Graphiurus & Murinus & $\begin{array}{l}\text { Woodland } \\
\text { dormouse }\end{array}$ \\
\hline- & - & Rhabdomys & Pumilio & $\begin{array}{l}\text { Striped } \\
\text { fieldmouse }\end{array}$ \\
\hline- & Muridae & Mus & Minutoides & Pygmy mouse \\
\hline- & - & Mastomys & Natalensis & $\begin{array}{l}\text { Natal } \\
\text { multimammate } \\
\text { mouse }\end{array}$ \\
\hline- & - & Michaelamys & Namaquensis & $\begin{array}{l}\text { Namaqua rock } \\
\text { mouse }\end{array}$ \\
\hline- & - & Otomys & Irroratus & Vlei rat \\
\hline- & - & Otomys & Sloggetti & $\begin{array}{l}\text { Sloggett's ice } \\
\text { rat }\end{array}$ \\
\hline- & - & Otomys & Unisulcatus & Bush Karoo rat \\
\hline- & - & Saccostomus & Campestris & Pouched mouse \\
\hline - & - & Dendromus & Melanotis & $\begin{array}{l}\text { Grey climbing } \\
\text { mouse }\end{array}$ \\
\hline- & - & Desmodillus & Auricularis & $\begin{array}{l}\text { Short-tailed } \\
\text { gerbil }\end{array}$ \\
\hline- & - & Gerbillurus & Paeba & $\begin{array}{l}\text { Hairy-footed } \\
\text { gerbil }\end{array}$ \\
\hline Primates & Cercopithecidae & Papio & Ursinus & $\begin{array}{l}\text { Chacma } \\
\text { baboon }\end{array}$ \\
\hline- & - & Chlorocebus & Pygerythrus & Vervet monkey \\
\hline \multirow[t]{2}{*}{ Eulipothyphla } & Soricidae & Myosorex & Varius & Forest shrew \\
\hline & & Erinaceus & Frontalis & Hedgehog \\
\hline Chiroptera & Nycteridae & Nycteris & Thebaica & $\begin{array}{l}\text { Egyptian slit- } \\
\text { faced bat }\end{array}$ \\
\hline - & Molossidae & Tadarida & Aegyptiaca & $\begin{array}{l}\text { Egyptian free- } \\
\text { tailed bat }\end{array}$ \\
\hline - & Vespertilionidae & Neoromicia & Capensis & $\begin{array}{l}\text { Cape serotine } \\
\text { bat }\end{array}$ \\
\hline Carnivora & Hyaenidae & Proteles & Cristata & Aardwolf \\
\hline- & - & Parahyaena & Brunnea & Brown hyaena \\
\hline- & Felidae & Acinonyx & Jubatus & Cheetah \\
\hline- & - & Panthera & Leo & Lion \\
\hline- & - & Caracal & Caracal & Caracal \\
\hline- & - & Felis & Silvestris & African wild cat \\
\hline- & - & Felis & Nigripes & $\begin{array}{l}\text { Black-footed } \\
\text { cat }\end{array}$ \\
\hline- & Viverridae & Genetta & Genetta & $\begin{array}{l}\text { Small-spotted } \\
\text { genet }\end{array}$ \\
\hline- & - & Genetta & Tigrina & $\begin{array}{l}\text { Large-spotted } \\
\text { genet }\end{array}$ \\
\hline- & - & Suricata & Suricatta & Meerkat \\
\hline- & - & Cynctis & Penicillata & $\begin{array}{l}\text { Yellow } \\
\text { mongoose }\end{array}$ \\
\hline- & - & Galerella & Pulverulenta & $\begin{array}{l}\text { Cape grey } \\
\text { mongoose }\end{array}$ \\
\hline- & - & Atilax & Paludinosus & $\begin{array}{l}\text { Marsh } \\
\text { mongoose }\end{array}$ \\
\hline
\end{tabular}

Table 1-A1 continues on the next column $\rightarrow$
TABLE 1-A1 (Continues...): The updated (2020) checklist of 68 mammal species in the Mountain Zebra National Park, Eastern Cape, South Africa. See text for details on the criteria used for inclusion.

\begin{tabular}{|c|c|c|c|c|}
\hline Order & Family & Genus & Species & Common name \\
\hline- & Canidae & Otocyon & Megalotis & Bat-eared fox \\
\hline - & - & Vulpes & Chama & Cape fox \\
\hline- & - & Canis & Mesomelas & $\begin{array}{l}\text { Black-backed } \\
\text { jackal }\end{array}$ \\
\hline- & Mustelidae & Aonyx & Capensis & $\begin{array}{l}\text { African clawless } \\
\text { otter }\end{array}$ \\
\hline- & - & Mellivora & Capensis & Honey badger \\
\hline- & - & Poecilogale & Albinucha & $\begin{array}{l}\text { White-naped } \\
\text { weasel }\end{array}$ \\
\hline- & - & Ictonyx & Striatus & Striped polecat \\
\hline Perissodactyla & Rhinocerotidae & Diceros & Bicornis & $\begin{array}{l}\text { Black } \\
\text { rhinoceros }\end{array}$ \\
\hline- & Equidae & Equus & zebra zebra & $\begin{array}{l}\text { Cape mountain } \\
\text { zebra }\end{array}$ \\
\hline Suiformes & Suidae & Potamochoerus & Larvatus & Bushpig \\
\hline- & - & Phacochoerus & Africanus & Warthog \\
\hline- & - & Syncerus & Caffer & Buffalo \\
\hline Ruminantia & Bovidae & Tragelaphus & Strepsiceros & Greater kudu \\
\hline- & - & Tragelaphus & Scriptus & Bushbuck \\
\hline- & - & Tragelaphus & Oryx & Eland \\
\hline- & - & Connochaetes & Gnou & $\begin{array}{l}\text { Black } \\
\text { wildebeest }\end{array}$ \\
\hline- & - & Alcelaphus & Buselaphus & Red hartebeest \\
\hline- & - & Damaliscus & $\begin{array}{l}\text { pygargus } \\
\text { phillipsi }\end{array}$ & Blesbok \\
\hline- & - & Oryx & gazelle & Gemsbok \\
\hline- & - & Sylvicapra & Grimmia & Common duiker \\
\hline- & - & Redunca & Fulvorufula & $\begin{array}{l}\text { Mountain } \\
\text { reedbuck }\end{array}$ \\
\hline- & - & Pelea & Capreolus & Grey rhebok \\
\hline- & - & Antidorcas & Marsupialis & Springbok \\
\hline- & - & Raphicerus & Campestris & Steenbok \\
\hline- & - & Oreotragus & Oreotragus & Klipspringer \\
\hline
\end{tabular}

